\title{
Biogenic sphalerite and galena formation in peatlands polluted by atmospheric deposition
}

\author{
B. SMIEJA-KRÓL ${ }^{1 *}$, M. PAWLYTA ${ }^{2}$, B. FiąKIEWICZ- \\ KOZIEŁ $^{3}$ AND M. KĄDZIOŁKA-GAWEŁ ${ }^{1}$ \\ ${ }^{1}$ University of Silesia, Katowice, Poland, (*correspondence: \\ beata.smieja-krol@us.edu.pl) \\ ${ }^{2}$ Silesian University of Technology, Gliwice, Poland \\ ${ }^{3}$ Adam Mickiewicz University, Poznań, Poland
}

Peatlands are redox-sensitive sediments where most metal-containing dust particles dissolve shortly after deposition on the surface. Studies on polluted peatlands showed that the metals are often re-sequestered in secondary reduced phases $[1,2]$.

Here, we combine scanning (SEM), transmission electron microscopy (TEM), and bulk elemental analyses to characterize the distribution, morphology, and structure of $\mathrm{Zn}$ and $\mathrm{Pb}$ sulfides formed in two peatlands located close to $\mathrm{Pb}$ Zn smelter. Additionally, Mössbauer spectroscopy is used to investigate Fe speciation.

Biogenic sulfide mineralization was found in metalenriched (up to $2,300 \mathrm{mg} \mathrm{Zn} / \mathrm{kg}, 1,100 \mathrm{mg} \mathrm{Pb} / \mathrm{kg}$ ) $\sim 30 \mathrm{~cm}$ layer, located $10 \mathrm{~cm}$ below the peat surface. $\mathrm{ZnS}$ is most abundant and occurs in the form of spheroids $(<1-6 \mu \mathrm{m})$, plant cell infillings, or pseudomorphs after $\mathrm{Ca}$ oxalate. $\mathrm{Pb}$ sulfides occur as small inclusions $(<1 \mu \mathrm{m})$ between $\mathrm{ZnS}$ or as flat irregular or square patches on plant root macrofossils.

TEM reveals that the $\mathrm{ZnS}$ is composed of low- and highdensity bands which has a polycrystalline sphalerite structure. Randomly oriented, $10-20 \mathrm{~nm}$ crystalline domains prevail in low-density regions. Large $(\sim 300 \mathrm{~nm})$, radially arranged crystals form the high-density bands. They are rich in planar defects and commonly nano-twinned. $\mathrm{PbS}$ is in the form of defect-free large $(>200 \mathrm{~nm})$ galena crystals.

No Fe sulfides were found, nor $\mathrm{Fe}$ is present in $\mathrm{Zn}$ and $\mathrm{Pb}$ sulfides. The Mössbauer spectroscopy indicates that the iron occurs entirely in the ferric state in the peat. Probably, the organic matter preserves the oxidation state of the airdeposited $\mathrm{Fe}$ allowing to precipitate the less common metal sulfides in the peat. The study gives insights into the formation of low-temperature biogenic metal sulfide deposits.

[1] Sonke et al. (2002) Sci Total Environ 292, 101-119. [2] Smieja-Król et al. (2010) Sci Total Environ 408, 5924-5931.

Acknowledgements: The research was funded by grant 2016/23/B/ST10/00781 from the National Science Centre, Poland. 